\title{
Influence of fertilizers on yield and its relationship with the quality of potato stubs in Vologda region
}

\author{
Olga Chukhina ${ }^{1 *}$, Anna Demidova ${ }^{1}$, and Tatyana Vasilyeva ${ }^{1}$ \\ ${ }^{1}$ Federal State Budgetary Educational Institution of Higher Education "Vologda State Dairy Farming \\ Academy by N.V. Vereshchagin", 160555, Vologda Oblast, Vologda, s. Dairy, Shmidta Str., 2, \\ Russia
}

\begin{abstract}
In the conditions of the Vologda Region on sod-podzolic soil, the calculated fertilization systems on average for 2015 - 2018 increased the yield of potato tubers by $41-66 \%$ compared to the minimum dose of fertilizers. The maximum starch content of $12.8 \%$ was observed when using an organomineral fertilizer system. The research shows a direct linear relationship between the content of "crude" protein and the yield of potato tubers.
\end{abstract}

\section{Introduction}

Potato cultivation is a branch of agriculture in the Russian Federation and the Vologda Region in particular, where personal subsidiary plots of the population prevail in the total volume of production, and as a result, this industry is characterized by low marketability and production instability.

Therefore, the problems concerning the development of new, demanded models for the development of potato growing, based on the achievements of science and its interaction with practice, which are guided by the needs of buyers and quick return on costs, are urgent.

One of the most important factors in increasing the yield and quality of agricultural crops is the rationalization of the use of fertilizers. It is most advisable to use fertilizers in a certain system with the existing alternation of crops in crop rotation (agrocenosis), since in this case not only the effect, but also the aftereffect of both organic and mineral forms, is taken into account most fully [1 -7].

\section{Methods}

In order to study the potential for obtaining a yield of potato tubers - $25 \mathrm{t} /$ ha using the minimum and calculated fertilization systems on sod-podzolic medium loamy soil, studies were carried out in 2015 - 2018. in the field stationary experiment. Experiment coordinates - 59017.520 'N.Sh. 39039.500 'V.D. According to the certificate of long-term experience

\footnotetext{
${ }^{*}$ Corresponding author: nv.goman@omgau.org
} 
No. 164, the experience is included in the register of the State network of experiments with fertilizers and other agrochemical means. The object and subject of research is potato culture and fertilizers. The experiment is carried out in a 4-field crop rotation: annual forage crops (vetch-oat mixture), winter rye, potatoes - varieties Elizaveta, Red Scarlet, barley, expanded in space and time. The experiment was carried out according to the scheme, which considered various models of the application of fertilization systems:

1 option - without the use of fertilizers - control,

2 option - using fertilizer when planting potato tubers $\mathrm{N}_{20} \mathrm{P}_{20}$,

3, 4 options - mineral fertilization systems, differing $\mathrm{Kb}$ of potassium use, respectively $\mathrm{N}_{125} \mathrm{P}_{50} \mathrm{~K}_{225}$ and ${ }_{\mathrm{N} 125} \mathrm{P}_{50} \mathrm{~K}_{270}$,

5 option - organo-mineral system, element equivalent to option $3 \mathrm{~N}_{70} \mathrm{P}_{15} \mathrm{~K}_{45}+40 \mathrm{t} / \mathrm{ha}$ of rotted manure.

Variants 3 and 5 - doses of applied fertilizers are calculated according to the planned balance coefficients of NPK use from organic and mineral fertilizers. The applied fertilization systems are calculated using the planned $\mathrm{Kb}$ of the use of nutrients to obtain the yield of potato tubers at the level of $25 \mathrm{t} / \mathrm{ha}$. Initially, in all variants of the experiment, it was planned to obtain a negative balance for $\mathrm{N}-(\mathrm{KB}-120 \%)$ and a zero balance for $\mathrm{P}$ (KB - 100\%) (BACKGROUND). For the element $-\mathrm{K}$ in the third and fifth versions of fertilization systems, a zero balance is planned, and in the fourth version - a positive balance. To calculate the doses of fertilizers, we took the standard indicators for the removal of nutrients 1 ton by the main product, taking into account by-products based on the results of previous years of research. Phosphorus - potassium and organic fertilizers were applied for fall plowing in the form of double superphosphate, potassium salt and rotted manure. Nitrogen fertilizers, mainly in the form of ammonium nitrate, were applied under pre-sowing cultivation. Nitrophos was added under the potatoes during planting (in option 2, only during planting). Potatoes were planted using a $\mathrm{CH}-4 \mathrm{~B}-1$ planter. The technology of cultivation of crops in the experiment included the technological methods generally accepted for the North-West zone. The research technique was discussed in more detail in publications earlier [8-13].

When calculating, the values of yield - potato tubers and tops were brought to standard moisture content. We used the standard methods of analysis of tubers and tops: after carrying out wet ashing according to K. Ginzburg, we determined: nitrogen according to Kjeldahl, phosphorus - on a photocolorimeter, potassium - on a flame photometer. Mathematical processing of research materials was carried out by the method of one-way analysis of variance using a computer and according to B.A. Dospekhov (1985).

Characteristics of the soil of the experimental site:

- $\quad$ sod-podzolic, granulometric composition - medium loamy

- $\mathrm{pH}_{\mathrm{KCl}} 4,9$

- $\quad$ the content of mobile phosphorus and exchangeable potassium, respectively 132 and $55 \mathrm{mg} / \mathrm{kg}$ of soil,

- humus $-2,56 \%$.

Fig. 1 shows the hydrothermal moistening coefficients (HMC) by months of research years in comparison with the long-term average values, calculated as the ratio of the amount of precipitation in millimeters at temperatures above $+10^{\circ} \mathrm{C}$, increased by 10 times to the amount of active temperatures for the same period in degrees Celsius (according to G.T.Selyaninov).

It can be seen that during the potato growing season, weather conditions in 2015, 2016, 2018, except for July, differed in less precipitation compared to the average long-term data. In 2017, the sum of active temperatures was below average values, a large amount of precipitation, which adversely affected the potato yield. 


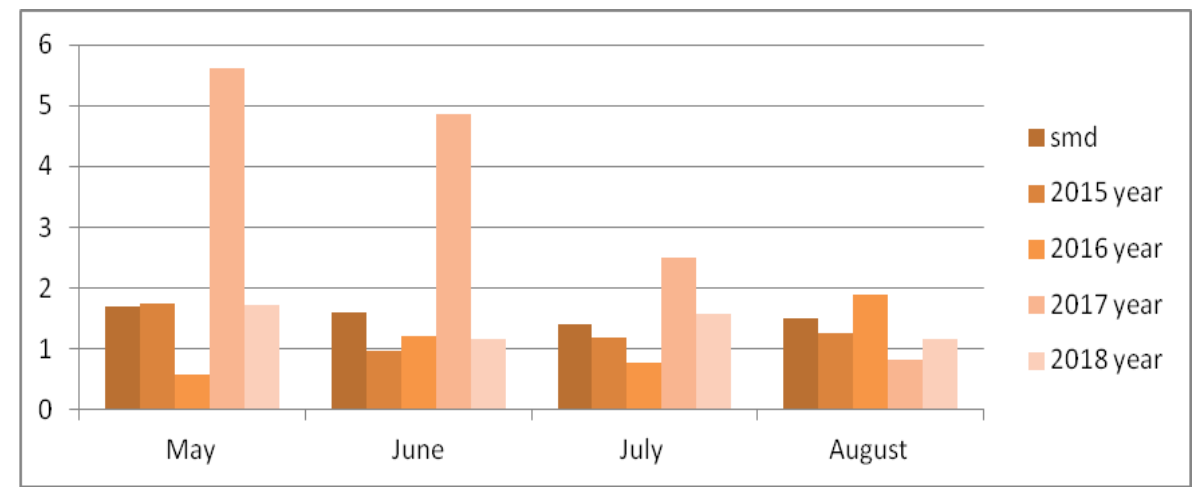

Fig. 1. State Customs Committee by months of 2015-2018 research years in comparison with longterm average values (lav).

In 2018, the yield of potato tubers was higher compared to 2015-2017. The use of N20P20 in three of the four studied years provided a significant increase in the yield of potato tubers. In 2017, the use of calculated fertilization systems (3 - 5 var.) Did not provide $2.8-19 \%$ of the planned level of tuber yield. In the rest of the research years - in 2015 (except for the calculated mineral fertilizer system (3 options)), in 2016, 2018, the studied calculation systems of fertilizers exceeded the planned level on average for 4 years of research by $14-30 \%$. Fertilizers increased the yield of tubers by $4.5-24$ t/ha in different years of research. [9-15] The studied calculation systems of fertilization of crops, except for the use of the calculated mineral fertilization system (3 options) in 2015, differed insignificantly in the yield of tubers in all the years of research (Table 1).

Table 1. Yield of potato tubers in 2015 - 2018, t/ha.

\begin{tabular}{|c|c|c|c|c|c|c|c|}
\hline Option & 2015 & 2016 & 2017 & 2018 & Average & \multicolumn{2}{|c|}{ Increase } \\
\cline { 7 - 9 } & & & t c.units/ha & $\%$ \\
\hline $\begin{array}{c}\text { Control (no } \\
\text { fertilizer) }\end{array}$ & 14,0 & 14,3 & 13,7 & 20,2 & 15,6 & - & - \\
\hline $\mathrm{N}_{20} \mathrm{P}_{20}$ & 18,5 & 21,4 & 18,3 & 30,5 & 22,2 & 6,6 & 42 \\
\hline $\mathrm{N}_{125} \mathrm{P}_{50} \mathrm{~K}_{225}$ & 24,3 & 29,6 & 20,2 & 40,5 & 28,6 & 13,0 & 83 \\
\hline $\mathrm{N}_{125} \mathrm{P}_{50} \mathrm{~K}_{270}$ & 27,7 & 32,6 & 24,3 & 43,8 & 32,1 & 16,5 & 106 \\
\hline $\begin{array}{c}\mathrm{N}_{70} \mathrm{P}_{15} \mathrm{~K}_{45}+40 \\
\text { т/га П. н. }\end{array}$ & 28,8 & 38,3 & 22,5 & 40,2 & 32,4 & 16,8 & 108 \\
\hline $\mathrm{HCP}_{05}$ & 2,9 & 6,1 & 5,2 & 5,5 & 6,6 & & \\
\hline
\end{tabular}

The crop yield as a result of the application of fertilizers increased by an average of 42 $108 \%$. The maximum yield of tubers of $32 \mathrm{t} / \mathrm{ha}$ was provided by the mineral system with the maximum dose of potash fertilizers and the organo-mineral fertilization system $(4,5$ options).

The yield of potato tops during the years of research increased with increasing doses of fertilizers. On average, over the years of research, fertilizers increased the yield of potato tops by 2.5-6.5 $\mathrm{t} / \mathrm{ha}$. The studied calculation systems of crop fertilization in terms of influence on the yield of tops differed insignificantly (3-5 options). The greatest value of the increase in the yield of tops to the control and fertilizers only during planting $\left(\mathrm{N}_{20} \mathrm{P}_{20}\right.$, 2op.) Was provided by the mineral system with the maximum dose of potash fertilizers and the organo-mineral fertilizer system (4, 5 options), respectively 3.9-4.0 t/ha (Fig. 2). 


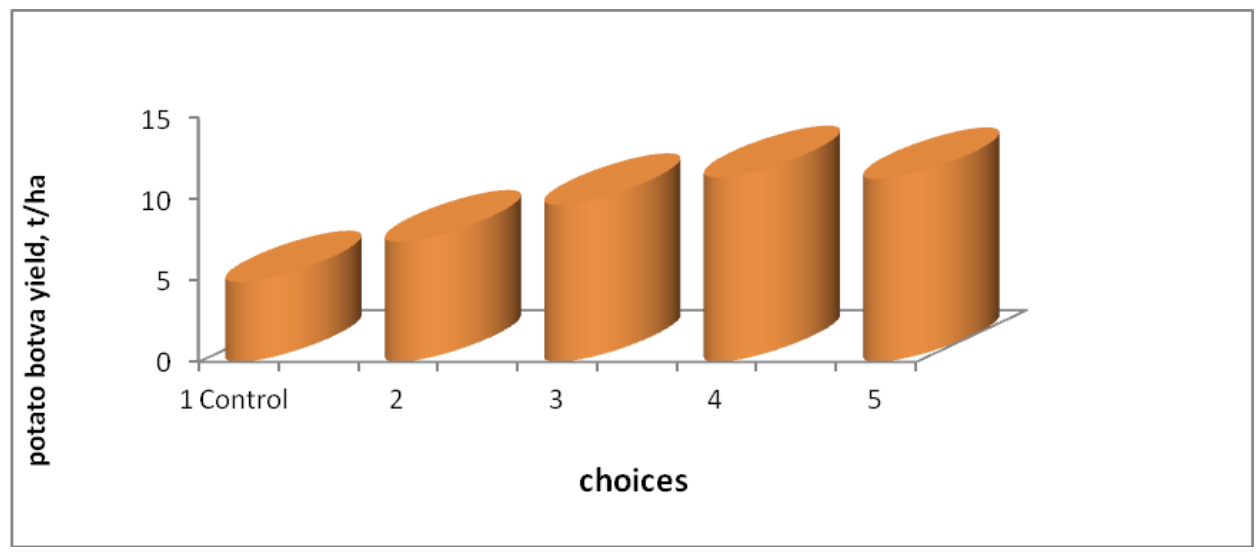

Fig. 2. Yield of potato tops by variants of the experiment, $t / h a$, on average for the period of research.

On average, for 2015-2018 research years, the use of fertilizers increased the content of "crude" protein in potato tubers by $0.36-1.38$ absolute $\%$ or by $4-14$ relative\% (Fig. 3).

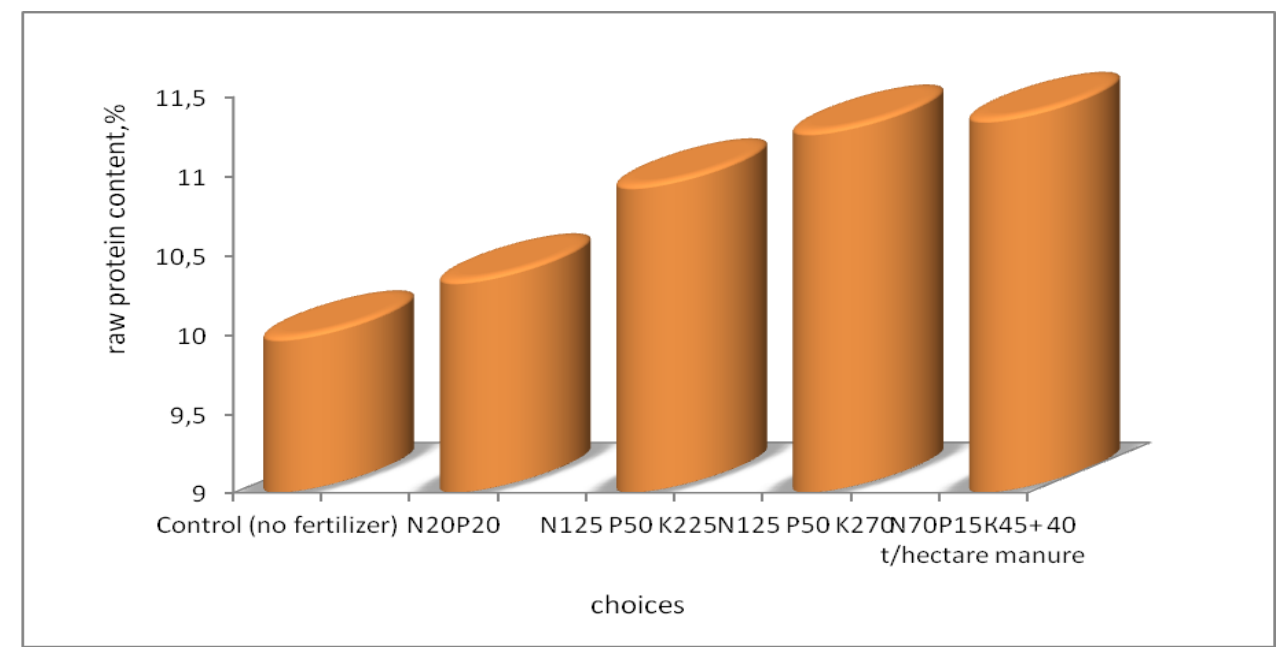

Fig. 3. "Crude" protein, its content in potato tubers by variants of the experiment, \%, on average for the period of research.

Fertilization during planting slightly increased the content of "crude" protein in potato tubers in comparison with the control by $4 \%$ in relative value. Mineral and organomineral fertilization systems (variants 3 and 5), equivalent in fertilizer dose, differed in their influence on the content of "crude" protein in tubers by only $4 \%$ in relative value. The content of "crude" protein in potato tubers in the variant with the maximum dose of potassium fertilizer $\left(\mathrm{N}_{125} \mathrm{P}_{50} \mathrm{~K}_{270}\right)$ and when using an organomineral fertilization system $\left(\mathrm{N}_{70} \mathrm{P}_{15} \mathrm{~K}_{45}+40 \mathrm{t} / \mathrm{ha}\right.$ of rotted manure) превышало контроль (без удобрений), в среднем на 1,3 абсолютного \% [10-15].

The proportion of sample variance attributable to the y-values predicted by the regression equation is expressed by the coefficient of determination.

In studies, there is a direct linear relationship between the content of "crude" protein and the yield of potato tubers (Fig. 4). 


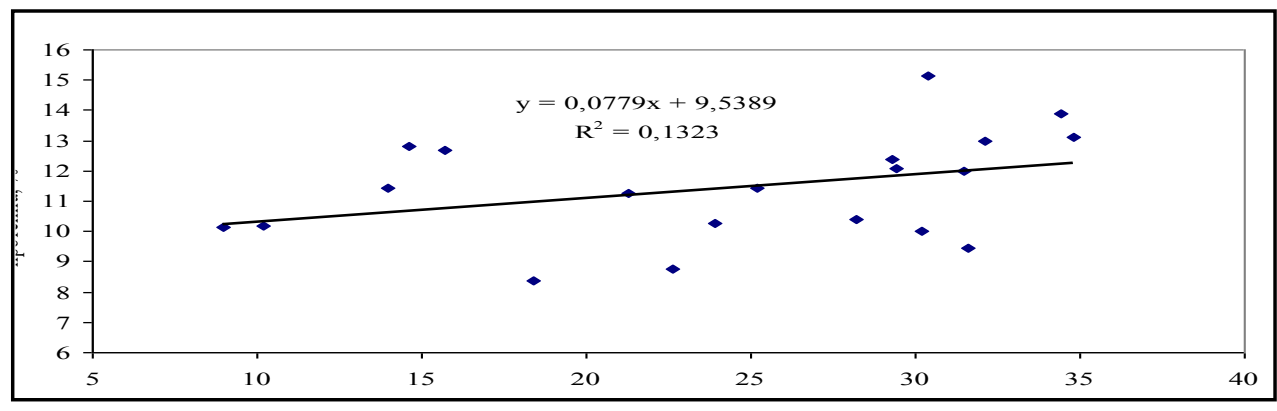

Fig. 4. The relationship between the "crude" protein in potato tubers and their yield.

In the case of potatoes, a high curvilinear relationship was obtained between the yield of tubers and the starch content $(\mathrm{R}=0.9175)$, which can be expressed by means of the analytical equation of the second-order parabola: with an increase in the yield of tubers, the starch content is initially practically at the same level, and then begins to decrease (Fig. 5).

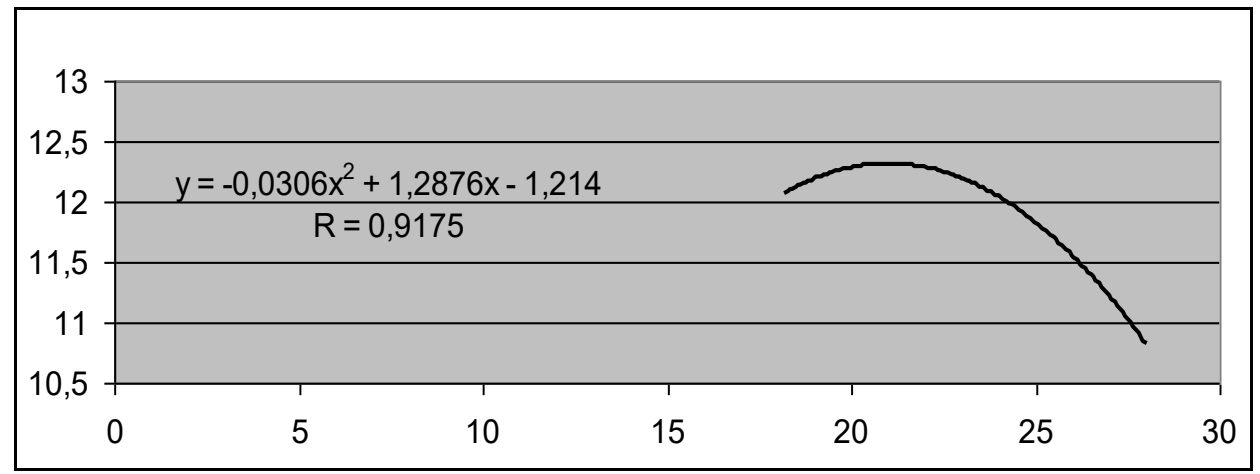

Fig. 5. Relationship between yield and starch content in potato tubers.

On average, for 2015-2018, the actual $\mathrm{Kb}$ of nitrogen use exceeded the planned ones by 8-33\% (3-5 options), which shows a significant use of nitrogen not only from fertilizers, but also from the nutrient solution of the soil. When planning the negative balance of the nutritional element on the potato, we got one, because the removal of the element by the crop significantly (by 8-33\%) exceeded the dose of the applied fertilizer (Fig. 6).

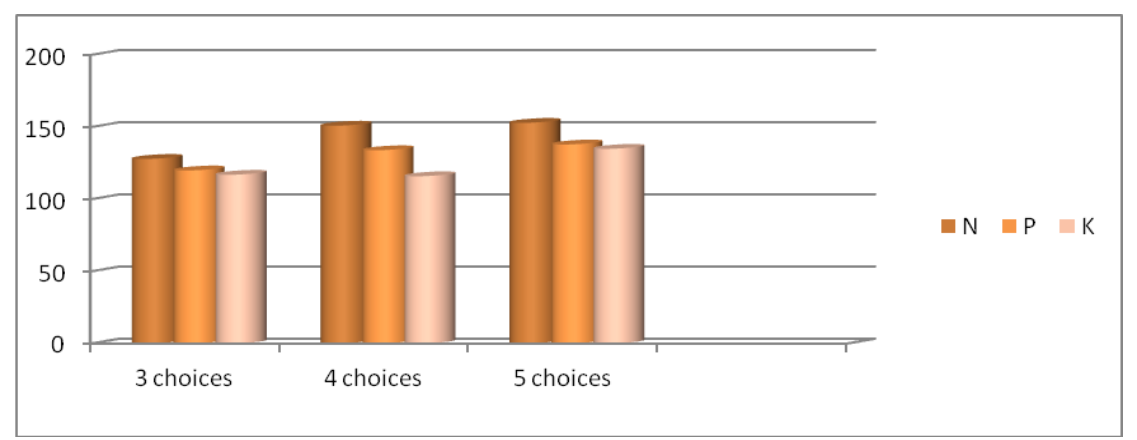

Fig. 6. The value of the indicators of the actual balance factors $(\mathrm{Kb})$ of the use of $\mathrm{N}, \mathrm{P}, \mathrm{K}$ fertilizers and soil, \%. 
Actual coefficients $\mathrm{Kb}$ of phosphorus element use exceeded the planned values by 20 $38 \%$, i.e. removal of the nutrient by the crop of tubers and tops was higher than the introduced dose. Consequently, part of the nutrient was used by the plants of the culture due to the mobile forms of the soil absorbing complex.

A similar situation, on average for 2015-2018. studies, developed and on the balance of potassium. The economic removal of the food element on the studied calculation systems (3-5 options) turned out to be higher than the applied doses of potash fertilizers, therefore the actual $\mathrm{Kb}$ exceeded the planned values by $17-36 \%$.

\section{Conclusion}

The results of four years of research on sod-podzolic medium loamy soil showed that the use of calculated fertilization systems provided $118-135 \%$ of the planned yield of potato tubers. The maximum starch content of $12.8 \%$ was observed when using an organomineral fertilizer system. The content of "crude" protein in potato tubers in the variant with the maximum dose of potassium fertilizer $\left(\mathrm{N}_{125} \mathrm{P}_{50} \mathrm{~K}_{270}\right)$ and when using an organomineral fertilization system $\left(\mathrm{N}_{70} \mathrm{P}_{15} \mathrm{~K}_{45}+40\right.$ tha of rotted manure) exceeded the control (without fertilizers), on average by $1.3 \%$ in absolute value.

\section{References}

1. R. Schafleitner, Crop Adaptation to Climate Change (Wiley, New York, 2011)

2. E. Runno-Paurson, Avta Agriculturae Scandinavica, Section B - Soil \& Plant Science, 63(1), 80-88 (2013)

3. J. Zhao, PLoS ONE, 13(9), e 0203538, 28-29 (2018)

4. P.A.J. VanOort, European Journal of Agronomy, 37(1), 11-22 (2012)

5. D.D. Tarkalson, Potato Research, 55(1), 41-58 (2012)

6. J. Tang, Agriculturaland Forest Meteorology, 256-257, 283-291 (2018)

7. V.V. Rogach, I.V. Poprotska, V.G. Kuryata, Visnyk of Dnipropetrovsk UniversityBiology Ecology, 24(2), 416-420 (2016), DOI: 10.15421/011656.

8. V.V. Rogach, Visnyk of Dnipropetrovsk University-Biology Ecology, 23(2), 221-224 (2015)

9. M. Naumann, Potato Research, 63(1), 1-17 (2019), doi.org/10.1007/s11540-01909430-3.

10. R. Mangani, Annual Research and Review in Biology, 9(5), 1-7 (2016), ARRB.9980/.2016

11. J. Śliwka, I. Tomczyńska, M. Chmielarz, et al., Plant Breeding and Seed Science 66, 63-73 (2014)

12. P. Wharton, and E. Wood, Early blight biology and control in potatoes (University of Idaho, 2013)

13. D. A. Andrianov, The System of Conducting Agricultural Production in the Republic of Bashkortostan (AS RB Gilem, Ufa, 2012)

14. N. M. Kleczewski, and D. S. Egel, Fungicide Resistance Management for Indiana Vegetables. Purdue Extension. Vegetable Diseases, pp. 1-5 (2012)

15. A. N. Smirnov, Zbornik Matice Srpske za Prirodne Nauke, 120, 135-144 (2011) 